\title{
COMUNICATION
}

\section{INTENSITY OF ANGULAR LEAF SPOT AND ANTHRACNOSE ON PODS OF COMMON BEANS CULTIVATED IN THREE CROPPING SYSTEMS}

\author{
Intensidade da mancha-angular e da antracnose em vagens de feijão em três sistemas de cultivo \\ Rogério Faria Vieira ${ }^{1}$, Trazilbo José de Paula Júnior², Hudson Teixeira ${ }^{3}$, Clibas Vieira ${ }^{4}$
}

\begin{abstract}
With the purpose to evaluate the intensity of angular leaf spot (ALS) and anthracnose (ANT) on pods, nine genotypes of common bean were planted in three cropping systems: monocrop (MC), monocrop grown on trellises (MCT), and intercrop with maize (ICM). In MC, beans were planted $0.5 \mathrm{~m}$ apart. Trelisses were set up with $1.8 \mathrm{~m}$ high bamboos and beans were sown $0.65 \mathrm{~m}$ apart. In ICM, beans were planted simultaneously with maize and in its rows. This cereal was sown $1.0 \mathrm{~m}$ apart with four plants per meter. Each cropping system was an independent trial installed close to each other. Climbing genotypes of beans most susceptible to ALS had less diseased pods in ICM than in both MC and MCT, but the less susceptible genotypes, regardless of their growth type, as well as the susceptible bush and semiclimbing genotypes, were similarly attacked by ALS in the three systems. ANT on pods of the susceptible bean cv. Pérola was less intense in MCT than in MC, and less intense in ICM than in MCT. ANT seed transmission was $11 \%, 9.1 \%$, and $4.4 \%$ when seeds come from MC, MCT, and ICM, respectively.
\end{abstract}

Index terms: Phaeoisariopsis griseola, Colletotrichum lindemuthianum, Phaseolus vulgaris, seed transmission.

\section{RESUMO}

Com o objetivo de avaliar a intensidade da mancha-angular (MA) e da antracnose (ANT) em vagens, nove genótipos de feijão foram plantados em três sistemas de plantio: monocultivo (MC), monocultivo com tutoragem artificial (MCT) e consórcio com milho (CCM). No MC, o feijão foi semeado no espaçamento entre fileiras de $0,50 \mathrm{~m}$. Para o MCT, utilizaram-se varas de bambu formando "Vs" invertidos com 1,8 m de altura, nos quais foi mantido o espaçamento entre fileiras de 0,65 m na base. No CCM, o feijão foi plantado simultaneamente ao milho e em suas fileiras. Esse cereal foi semeado no espaçamento de 1,0 m, com quatro plantas por metro. Cada sistema de cultivo foi um ensaio independente, todos instalados na mesma área. Os genótipos trepadores mais suscetíveis à MA apresentaram menos vagens doentes no CCM que no MC e MCT, mas os genótipos menos atacados pela MA, independentemente do tipo de crescimento, como também os outros genótipos suscetíveis de porte anão e semitrepador, foram infectados de forma semelhante nos três sistemas de plantio. A ANT nas vagens do cv. Pérola foi menos intensa no MCT que no MC, e menos intensa no CCM que no MCT. A transmissão da ANT pela semente foi de $11 \%, 9,1 \%$ e 4,4 \% quando as sementes foram colhidas no MC, MCT e CCM, respectivamente.

Termos para indexação: Phaeoisariopsis griseola, Colletotrichum lindemuthianum, Phaseolus vulgaris, transmissão por semente.

\section{(Received in may 2, 2007 and approved in august 14, 2008)}

In the state of Minas Gerais, Brazil, common bean (Phaseolus vulgaris L.) is cultivated in many cropping systems. In general, monocrop is the most common system. On small farms, bean is usually planted in association with maize and other crops. Monocrop of bean grown on trellises is made for climbing beans, especially for snap beans. It is not clear yet the influence of the cropping systems on the severity of angular leaf spot (ALS) caused by Phaeoisariopsis griseola (Sacc.) Ferraris. Normally, anthracnose (ANT), incited by Colletotrichum lindemuthianum (Sacc. \& Magnus) Briosi \& Cavara, is more intense in monocrop than on bean intercropped with maize (Vieira, 1999), but the differences among systems is not well quantified and there is no information available regarding the monocrop of bean grown on trellises. The purpose of this research was to evaluate the intensity of ALS and ANT on pods of beans cultivated in three cropping systems.

Trials were carried out in the spring-summer of 2000/ 2001, in Coimbra, MG, Brazil, using the climbing common beans Preto 1379, P.I. 282.063, P.I. 310.740, and Compuesto Negro Chimaltenango; the semiclimbing Ouro Negro and

\footnotetext{
${ }^{1}$ Engo Agro, D.Sc., Pesq. Embrapa/EPAMIG-CTZM - Vila Gianetti 46 - Cx. P. 216 - 36.570-000 - Viçosa, MG - rfvieira@epamig.br Engo Agro, Ph.D., Pesq. EPAMIG-CTZM - Vila Gianetti 46 - Cx. P. 216 - 36.570-000 - Viçosa, MG - trazilbo@epamig.ufv.br ${ }^{3} E_{n g}^{\circ}$ Agro, D.Sc., Pesq. EPAMIG-CTZM - Vila Gianetti 46 - Cx. P. 216 - 36.570-000 - Viçosa, MG - hudsont@epamig.br ${ }^{4}$ In memoriam.
} 
Pérola, and the bush bean Trujillo 2. They were cultivated as monocrop (MC), monocrop grown on trellises (MCT), and intercrop with maize (ICM). In MC, beans were planted $0.5 \mathrm{~m}$ apart. Trellises were set up with $1.8 \mathrm{~m}$ high bamboos and beans were sown $0.65 \mathrm{~m}$ apart. In ICM, beans were planted simultaneously with maize and in its line. This cereal was sown $1.0 \mathrm{~m}$ apart with 4 plants per meter. Twelve seeds per meter of beans were used. A randomized complete-block design with four replications was used. Three independent trials were installed close to each other. Pods with symptoms of ALS and ANT and number of lesions per pod of these diseases were obtained from 50 pods in maturation taken from each plot and trial. Seeds of the most susceptible cultivar to ANT were germinated in sand and in conditions of high moisture to evaluate the percentage of seeds transmitting the fungus. Four replications of 100 seeds were used. Methodology details of the research on field and yields achieved can be found in Vieira et al. (2003). For data which distributions were not normal, means were transformed by $\sqrt{x+0.5}$ before analysis of variance. Means were compared using Duncan test at $5 \%$ of probability.

Five cultivars had $50 \%$ or more pods with sympytoms of ALS in MC (Table 1). Both Ouro Negro and P.I. 282.063 were among the genotypes with higher number of pods expressing symptoms of ALS in MC, but just Ouro Negro had a large number $(76 \%$ ) of pods diseased in ICM. In regarding to the number of lesions per pod, Ouro Negro and P.I. 282.063 had similar behavior in the three systems (Table 1). Differently of Ouro Negro (semiclimbing) and Trujillo 2 (bush), the climbing beans Preto 1379, P.I. 282.063, and P.I. 310.740 showed a tendency of reduction in the number of pods with symptoms of ALS in ICM compared with MC (Table 1). This tendency was also kept when the number of lesions per pod was considered (Table 1). It is possible that bush and semiclimbing beans were more exposed to the high moisture close to the soil under the maize than were climbing beans. As longer as the period of continuous moisture on leaves, as higher will be the number of lesions per plant (Dalla Pria et al., 1999). Both Pérola and C.N. Chimaltenango were resistants to ALS and their pods were similarly infected in the three systems (Table 1). Woolley \& Davis (1991) wrote that "intercropping reduced ALS in a susceptible cultivar, although it apparently increased in a more tolerant cultivar". Our results support partially this statement. According to Vieira (1999), the information about the effect of the row intercropping on the severity of ALS on common bean is controversial. He believed that the physical barrier of maize could reduce spores dispersion, but the higher moisture in this association would favor the spore germination and the infection of common bean plants.
Thus, depending on environment, intercropping would favor or disfavor the disease.

In MC, Pérola had the highest number of pods with symptoms of ANT (Table 2). In MCT, Pérola did not differ significantly from both cultivar Trujillo 2 and P.I. 282.063. In ICM, Trujillo 2 had the highest number of diseased pods, followed by Pérola, P.I. 282.063, and P.I. 310.740. Both Pérola and P.I. 282.063 had the highest number of lesions of ANT per pod in MC, but they did not differ significantly from Trujillo 2 and P.I. 310.740 in the other systems. Comparing the three systems, the results indicate that in the susceptible cultivar Pérola diseased pods were reduced in ICM and MCT compared with MC, but systems did not clearly influence intensity of ANT in the tolerant genotypes.

Comparing the number of pods of Pérola with symptoms of ANT in MC with those in MCT, the reduction was of $75 \%$ (using original data for calculation). The reduction achieved $89 \%$ when MC is compared with ICM (Table 2). Using the number of lesions of ANT per pod for comparison, the percentages were lower: $48 \%$ and $58 \%$, respectively (Table 2 ). The bean population was almost the same in monocrop systems (an average of 205,000 plants per hectare) and of 85,000 per hectare in ICM (data not showed). Thus, the lower ANT intensity in MCT compared with MC is probably related to the height achieved by the plants and not to plant population. We believe that bean plants in MCT system had the canopy ventilation improved and were exposed to more solar radiation compared with plants in MC. Consequently, the environment was less favorable to ANT in the former system. ICM has additional conditions unfavorable to conidia dissemination, i.e., larger distance between bean rows and the physical barrier of maize plants. In MC, Pérola had $11 \%$ of seeds transmitting $C$. lindemuthianum. In MCT, it had 9.1\%; and when harvested in ICM $4.4 \%$ of seeds transmitted the fungus (data not showed). Most of the authors found that ANT is more severe to common beans in monocrop than when it is sown in the same maize line (Vieira, 1999). In this research we have confirmed this statement, but just for the cv. Pérola, the most susceptible to ANT in MC.

In conclusion, for susceptible climbing genotypes, ALS is less intense on pods harvested from ICM system compared with those from both MC and MCT systems. Less susceptible genotypes, regardless of their growth type, as well as susceptible bush and semiclimbing genotypes, have the same ALS intensity on pods in the three systems. The cultivar Pérola, highly susceptible to ANT in MC, has pods and seeds less infected by $C$. lindemuthianum in MCT than in MC, and less infected pods and seeds in ICM than in MCT. 
Table 1 - Intensity of angular leaf spot on pods of bean genotypes in three cropping systems.

\begin{tabular}{lccc}
\hline Genotype & Monocrop (MC) & Monocrop grown on trellises (MCT) & Intercrop with maize (ICM) \\
\cline { 2 - 4 } Ouro Negro & \multicolumn{3}{c}{ Percentage of pods with symptoms of angular leaf spot } \\
\cline { 2 - 4 } Pérola & $82.0 \mathrm{a}^{1}$ & $61.0 \mathrm{ab}$ & $76.0 \mathrm{a}$ \\
Trujillo 2 & $18.0 \mathrm{c}$ & $29.4 \mathrm{c}$ & $20.0 \mathrm{~d}$ \\
Preto 1379 & $56.4 \mathrm{~b}$ & $68.4 \mathrm{ab}$ & $52.0 \mathrm{~b}$ \\
P.I. 282.063 & $58.4 \mathrm{~b}$ & $55.0 \mathrm{ab}$ & $38.4 \mathrm{bc}$ \\
P.I. 310.740 & $79.4 \mathrm{a}$ & $77.4 \mathrm{a}$ & $46.0 \mathrm{~b}$ \\
C.N. Chimaltenango & $50.0 \mathrm{~b}$ & $48.0 \mathrm{bc}$ & $40.0 \mathrm{bc}$ \\
Mean & $22.4 \mathrm{c}$ & $30.0 \mathrm{c}$ & $22.4 \mathrm{~cd}$ \\
\hline & 52.4 & 52.8 & 42.2 \\
Ouro Negro & & Number of lesions of angular leaf spot per pod & $2.04(3.72) \mathrm{a}$ \\
Pérola & $2.20{ }^{2}(4.34) \mathrm{a}$ & $1.95(3.33) \mathrm{a}$ & $1.33(1.27) \mathrm{c}$ \\
Trujillo 2 & $1.33(1.26) \mathrm{c}$ & $1.41(1.49) \mathrm{b}$ & $1.54(1.89) \mathrm{bc}$ \\
Preto 1379 & $1.66(2.26) \mathrm{b}$ & $1.89(3.10) \mathrm{a}$ & $1.46(1.62) \mathrm{c}$ \\
P.I. 282.063 & $1.69(2.39) \mathrm{b}$ & $1.55(1.89) \mathrm{b}$ & $1.77(2.68) \mathrm{ab}$ \\
P.I. 310.740 & $2.28(4.73) \mathrm{a}$ & $1.94(3.31) \mathrm{a}$ & $1.50(1.76) \mathrm{bc}$ \\
C.N. Chimaltenango & $1.62(2.14) \mathrm{b}$ & $1.63(2.16) \mathrm{b}$ & $1.63(2.20) \mathrm{bc}$ \\
\hline Mean & $1.39(1.43) \mathrm{c}$ & $1.60(2.08) \mathrm{b}$ & $1.61(2.17)$ \\
\hline
\end{tabular}

${ }^{1}$ Means followed by the same letter in a column are not significantly different by Duncan's test $(\mathrm{P}<0.05)$.

${ }^{2}$ Data previously transformed by $\sqrt{x+0.5}$. Number in parentheses refers to original data. Fifty pods per plot were evaluated. Average of four replications.

Table 2 - Intensity of anthracnose on pods of bean genotypes in three cropping systems.

\begin{tabular}{|c|c|c|c|}
\hline \multirow[t]{2}{*}{ Genotype } & Monocrop (MC) & Monocrop grown on trellises (MCT) & Intercrop with maize (ICM) \\
\hline & \multicolumn{3}{|c|}{ Percentage of pods with symptoms of anthracnose } \\
\hline Ouro Negro & $0.71^{1}(0.00) \quad d^{2}$ & $0.71(0.00) \mathrm{c}$ & $0.71(0.00) \mathrm{d}$ \\
\hline Pérola & $4.82(46.00) \mathrm{a}$ & $2.38(11.50) \mathrm{a}$ & $1.70(5.00) \mathrm{b}$ \\
\hline Trujillo 2 & $2.22(9.50) \quad b$ & $1.81(6.00) a b$ & $2.26(10.00) \mathrm{a}$ \\
\hline Preto 1379 & $1.10(1.50) \mathrm{cd}$ & $0.93(1.00) \mathrm{bc}$ & $1.05(1.50) \mathrm{cd}$ \\
\hline P.I. 282.063 & $1.54(4.00) \mathrm{c}$ & $1.91(8.00) \mathrm{ab}$ & $1.48(3.50) \mathrm{bc}$ \\
\hline P.I. 310.740 & $0.71(0.00) \mathrm{d}$ & $0.97(1.00) \mathrm{bc}$ & $1.40(3.00) \mathrm{bc}$ \\
\hline C.N. Chimaltenango & $0.71(0.00) \quad \mathrm{d}$ & $0.93(1.00) b c$ & $0.84(0.50) \mathrm{d}$ \\
\hline \multirow[t]{2}{*}{ Mean } & $1.68(8.72)$ & $1.38(4.08)$ & $1.35(3.36)$ \\
\hline & \multicolumn{3}{|c|}{ Number of lesions of anthracnose per pod } \\
\hline Ouro Negro & $0.71(0.00) \mathrm{d}$ & $0.71(0.00) \mathrm{c}$ & $0.71(0.00) \mathrm{c}$ \\
\hline Pérola & $1.75(2.58) \mathrm{ab}$ & 1.35 (1.34) abc & $1.26(1.08) \mathrm{ab}$ \\
\hline Trujillo 2 & $1.39(1.45) b c$ & $1.79(2.87) \mathrm{a}$ & 1.43 (1.57) a \\
\hline Preto 1379 & $1.18(1.00) \mathrm{c}$ & $0.88(0.37) b c$ & $0.97(0.50) b c$ \\
\hline P.I. 282.063 & $1.89(3.31) \mathrm{a}$ & $1.52(2.07) \mathrm{ab}$ & $1.56(2.08) \mathrm{a}$ \\
\hline P.I. 310.740 & $0.71(0.00) \mathrm{d}$ & $1.22(1.25) \mathrm{abc}$ & $1.40(1.50) \mathrm{a}$ \\
\hline C.N. Chimaltenango & $0.71(0.00) \mathrm{d}$ & $0.84(0.25) b c$ & $0.84(0.25) \mathrm{c}$ \\
\hline Mean & $1.19(1.19)$ & $1.19(1.17)$ & $1.17(1.00)$ \\
\hline
\end{tabular}

${ }^{1}$ Data previously transformed by $\sqrt{x+0.5}$. Number in parentheses refers to original data. Fifty pods per plot were evaluated. Average of four replications.

${ }^{2}$ Means followed by the same letter in a column are not significantly different by Duncan's test $(\mathrm{P}<0.05)$. 


\section{ACKNOWLEDGEMENTS}

T.J. PAULA JR. and R.F. VIEIRA are supported by CNPq (Brasília, Brazil). H. TEIXEIRA is supported by FAPEMIG (Belo Horizonte, Brazil).

\section{BIBLIOGRAPHY}

DALLA PRIA, M.; SILVA, O.C. da; COSTA, J.L. da S.; SOUZA, E.D. de T.; BERNI, R.F. Diagnose de doenças. In: CANTERI, M.G.; DALLA PRIA, M.; SILVA, O.C. da. Principais doenças fúngicas do feijoeiro: orientações para manejo econômico e ecológico. Ponta Grossa: UEPG, 1999. p.17-34.
VIEIRA, C. Estudo monográfico do consórcio milhofeijão no Brasil. Viçosa, MG: UFV, 1999. 183p.

VIEIRA, C.; VIEIRA, R.F.; CARDOSO, A.A. Behavior of climbing and semiclimbing common bean cultivars under different cropping systems. Revista Ceres, Viçosa, v.50, n.291, p.621-640, 2003.

WOOLLEY, J.; DAVIS, J.H.C. The agronomy of intercropping with beans. In: SCHOONHOVEN, A. van; VOYSEST, O. (Eds.). Common beans: research for crop improvement. Wallingford: CAB International, 1991. p.707-735. 